\title{
Activated carbon production from wastes: profitability index and product cost reduction method
}

\author{
Odesola I. F and Daramola, N. O
}

\author{
Department of mechanical engineering, University of Ibadan, Ibadan, Nigeria \\ ABSTRACT
}

\begin{abstract}
A previous paper on developing a national capability for the manufacture of activated carbon from agricultural waste by the same authors was considered. In the said paper, the process flow diagram for the manufacture of Granular Activated Carbon from three agricultural wastes namely coconut shell, oil-palm shells and sugarcane bagasse was provided and the plant's economic analysis done. The objectives of this study were to investigate selling price reducing options and profitability of the investment discussed. In the study, the profitability indexes for the overall plant projects for the three plants were found. The effect of equipment cost reduction on the total productive cost was also examined. For the steam activation of coconut shell, successive reduction by $10 \%$ in the overall equipment cost was found reduce the corresponding Product cost geometrically by values ranging from $2.44-1.22 \%$ for ten successive reductions. The profitability index was between 0.057 and $4.07 \%$ respectively for the $1^{\text {st }}$ to the $11^{\text {th }}$ year. The steam activation of sugarcane bagasse was different, successive reduction by $10 \%$ in the overall equipment cost reduce the corresponding Product cost also geometrically by values ranging from 2.85-3.69\% (increasing with each reduction) also for 10 successive reductions. The profitability index was between 0.09 and $3.7 \%$ respectively for the $1^{\text {st }}$ to the $11^{\text {th }}$ year. And for the phosphoric activation of oil-palm shell, successive reduction by $10 \%$ in the overall equipment cost was found reduce the corresponding Product cost geometrically by values ranging from 4.58-2.88\% (decreasing with each reduction as in steam activation of coconut shells). The profitability index was between -1.08 and $2.12 \%$ respectively for the $1^{\text {st }}$ to the $11^{\text {th }}$ year. In addition, an excel software to simulate the economic analysis previously done and output the key costs after the simulation.
\end{abstract}

Keyword:-Granular Activated carbon, coconut shell, oil-palm shell, sugarcane bagasse, profitability Index, Total product Cost, Total Equipment cost.

\section{INTRODUCTION}

Profitability is simply the measure of the amount of profit that can be obtained form a given situation (Holland et al, 1973). The profit goal of a company is to maximise income above the cost of the capital which must be invested to generate the income (Baasel, 1976). if the goal were to maximize profit, then any investment would be accepted which would give profit no matter how low the return or how great the cost. (Peters et al, 1958).

For a plant like the activated plant developed before, it is necessary to know how much profit can be obtained versus the cost involved. This will help investors in making decision as to where and how best to invest. In a plant like the activated carbon plant where the cost are relatively high, the rate of return, rather than the total amount of profit is a more important profitability factor in determining its suitability for investment.

Four methods are generally acceptable for profitability evaluation namely:

1. Rate of return on investment

2. Discounted cash flow based on full-life performance

3. Net present worth

4. Capitalised costs

5. Payout period.

The method used for his study is the rate of return on investment based on discounted cash flow but with the use of continuous interest compounding. The choice of this method is based on its taking into account the time value of money and is based on the amount on investment that in unreturned at the end of each year during the estimated life of the project (Park, et al, 1973). The rate of return by this method 
is equivalent to the maximum interest rate at which money can be borrowed to finance the project under condition where the net cash flow to the project over its useful life would be sufficient to pay all principal and interest accumulated on the outstanding principal. (Peters et al, 1958). This maximum interest rate is known as the discounted cash flow rate of return or profitability index.

Chilton Ng, Wayne Marshall, Ramu M. Rao, Rishipal R. Bansode, Jack N. Losso and Ralph J. Portier's "Granular Activated Carbons from Agricultural Byproducts: Process Description and Estimated Cost of Production" described a process for producing activated carbon from three agricultural process namely; steam activation of sugarcane bagasse, steam activation of pecan shells and phosphoric acid activation of pecan shells.

Odesola I.F and Daramola O.N developed a national capability for the manufacture of activation carbon from three agricultural wastes namely, coconut shells, oil-palm shells and sugarcane bagasse. They described the steam activation of coconut shell, steam activation of sugarcane of sugarcane bagasse, and phosphoric activation of oil-palm shells in which they also did the economic analysis of the process.

\section{METHODS}

Assumptions: The assumptions made for the analysis are as follows:

I. The project life is taken as the equipment life and is 11 years as given by Peter and Timmerrhaus in their book, Plant Design and Economics for Chemical Engineers for chemical processing equipment.

II. The annual depreciation used is the one evaluated in the considered project.

III. The salvage value of the combined plant equipment is taken as the $10 \%$ of the purchased equipment cost delivered.

\section{a. Profitability Index}

Peter and Timmerrhaus in their book used the rate of return on investment based on discounted cash flow with the use of continuous interest compounding method to compute the profitability index of a project (table 3, page 320). The method was reapplied for the plant but modified to suit the current situation. In the method, the cash position given was modified for the case of the project as:

Cash position at time $n=$ present value of cash flow to project - present value of fixed capital investment + present value of terminal fixed capital investment, working capital investment and salvage value based on interest compounded continuously for $\mathrm{n}$ years present value of working capital investment.

This can be written as:

Cash position at time $\mathrm{n}=$ (annual constant cash flow to project $)\left(e^{r n}-1\right) / 1$ - fixed capital investment $\left(e^{r n}\right)-$ working capital investment $\left(\mathrm{e}^{\mathrm{rn}}\right)+$ (terminal fixed capital investment, working capital investment and salvage value $)\left(1 / \mathrm{e}^{\mathrm{rn}}\right)$ equation 1

The values of the parameters needed to solve have already been calculated in the economic analysis of the plants in the previous work. This are excerpted given in the table below:

1. Steam activation of coconut shell:

\begin{tabular}{|l|l|}
\hline Fixed capital investment & $\mathrm{N} 727,080,590.40$ \\
\hline Working capital investment & $\mathrm{N} 109,062,088.60$ \\
\hline Annual depreciation & $\mathrm{N} 72,708,059.04$ \\
\hline Annual qty. Produced & $\mathrm{N} 1,500,000$ \\
\hline Profit/unit & $\mathrm{N} 40.255$ \\
\hline Total annual profit & $\mathrm{N} 60,383,050.24$ \\
\hline
\end{tabular}

2. Steam activation of sugarcane bagasse

\begin{tabular}{|l|l|}
\hline Fixed capital investment & $\mathrm{N} 809,906,578.00$ \\
\hline Working capital investment & $\mathrm{N} 121,485,986.70$ \\
\hline Annual depreciation & $\mathrm{N} 80,990,657.80$ \\
\hline Annual qty. Produced & $\mathrm{N} 582,000.00$ \\
\hline Profit/unit & $\mathrm{N} 108.454$ \\
\hline Total annual profit & $\mathrm{N} 62,559,398.56$ \\
\hline \multicolumn{2}{|c|}{ 3. Phosphoric acid activation of oil-palm shells } \\
\hline Fixed capital investment & $\mathrm{N} 809,906,578.00$ \\
\hline Working capital investment & $\mathrm{N} 121,485,986.70$ \\
\hline Annual depreciation & $\mathrm{N} 80,990,657.80$ \\
\hline Annual qty. Produced & $\mathrm{N} 582,000.00$ \\
\hline Profit/unit & $\mathrm{N} 108.454$ \\
\hline Total annual profit & $\mathrm{N} 62,559,398.56$ \\
\hline
\end{tabular}

The table 1, table 3 and table 5 in appendix 1, 2 and 3 respectively contains this computations of this parameters with equation 1.

The profitability index is the $r$ (nominal continuous interest rate) at which the right-hand-side of equation 1 is zero. To determine this value of $r$ at the end of each year, Microsoft Office Excel 2007 Goal Seek function was used. These values are given in table 2, table 4 and table 6 of appendix 1, 2 and 3 respectively.

Graphs of cash position Vs time in years, and that of the profitability index Vs time in years for the three processes are given in figure 1 and 2, 3 and 4 , and 5 and 6 of appendix 1, 2 and 3 respectively. 
Simulation for the cost analysis of the activation of each of the materials: The prices of equipments used in the project are based on information from fabricators previous works. The fact that prospective investors could explore less expensive equipments of similar quality is not overlooked. For example some fabricators in Nigeria have proven their excellence in the fabrication of some of this equipment. Raw materials could also be sourced at a cheaper rate based on some factors that affects their prices. As a result of this, a simulation of the cost is provided (Excel file simulation.xIsm). The simulation was written with excel VBA and just prompt a user for prices of the variables used in the economic analysis calculation. When prices are entered and the simulate button in the form that appears is clicked, excel does the calculation and when the escape button is clicked excel provides for the user in a message box the total capital investment, the manufacturing cost, the total product cost and the selling price/Kg. Appendix $\mathrm{i}-\mathrm{H}$

Equipment cost variation with total productive cost: The total equipment cost delivered was varied with the total productive cost to investigate the effect of the former on the latter. This was carried out by reducing the total equipment cost delivered by $10 \%$ successively and simulating to calculate the total product cost. (table 7, 8 and 9, appendix 4-6). The resulting product costs were plotted versus the equipment costs(figure 7, 9 and 11, appendix 4-6). A bar chart of the percentage reduction in the total product costs with each $10 \%$ percent reduction in equipment costs were also plotted. Shown in figure 8, 10, and 12 of Appendix 4-6.

CONCLUSION: In this work, the profitability index of the proposed three projects was found. The rate of return by this method is equivalent to the maximum interest rate at which money can be borrowed to finance the project under condition where the net cash flow to the project over its useful life would be sufficient to pay all principal and interest accumulated on the outstanding principal. And so the result of the study shows that the maximum interest rate at which the money can be borrowed to finance the project for profitability for the steam activation of coconut shell is $4.7 \%$ to be paid at the $11^{\text {th }}$ year, $3.7 \%$ for the steam activation of sugarcane bagasse and $2.12 \%$ for the phosphoric acid activation of oil-palm shells all to be paid at the end of the useful life of the equipments. $11^{\text {th }}$ year as given by Peters, M., and Timmerhaus, K. For the equipment for chemical and allied processes.

For the three processes, reduction in the equipment costs reduces the total product cost with the percentage reduction increasing reducing at successive reductions for the steam activation of coconut shells and the phosphoric activation of oilpalm shell but reducing with increasing reductions for the steam activation of sugarcane bagasse.

The developed simulation program that allows the prospective investors enter costs into the calculation excel sheet for calculation is a good tool, in that it makes it possible and easier to even start cost savings strategies even before the project begins.

\section{APPENDIX 1: STEAM ACTIVATION OF COCONUT SHELL}

\begin{tabular}{|c|c|c|c|c|c|c|c|c|c|c|}
\hline $\mathrm{n}$ & $\stackrel{e}{a}$ & 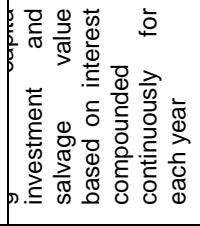 & $\begin{array}{l}\text { I } \\
\overrightarrow{1} \\
\bar{E}^{\prime}\end{array}$ & 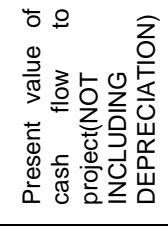 & 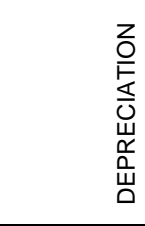 & 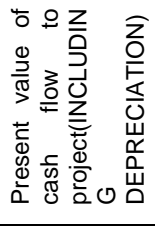 & $\bar{E}_{0}$ & 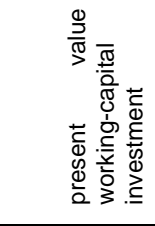 & 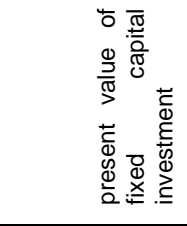 & 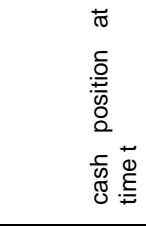 \\
\hline 1 & 0.961 & $816,597,311$ & 1.0200 & $61,588,374$ & $72,708,059$ & $-11,119,684$ & 1.040 & $113,444,909$ & $756,299,396$ & $\begin{array}{l}- \\
64,266,679 . \\
\end{array}$ \\
\hline 2 & 0.924 & $785,048,961$ & 2.081 & $125,651,767$ & $72,708,059$ & $52,943,708$ & 1.082 & $118,003,860$ & $786,692,403$ & $-66,703,593$ \\
\hline 3 & 0.889 & $754,719,446$ & 3.185 & $192,289,643$ & $72,708,059$ & $119,581,584$ & 1.126 & $122,746,019$ & $818,306,797$ & $-66,751,786$ \\
\hline 4 & 0.854 & $725,561,680$ & 4.332 & $261,605,460$ & $72,708,059$ & $188,897,401$ & 1.171 & $127,678,749$ & $851,191,663$ & $-64,411,330$ \\
\hline 5 & 0.821 & $697,530,392$ & 5.527 & $333,706,836$ & $72,708,059$ & $260,998,777$ & 1.218 & $132,809,708$ & $885,398,056$ & $-59,678,594$ \\
\hline 6 & 0.790 & $670,582,063$ & 6.769 & $408,705,711$ & $72,708,059$ & $335,997,652$ & 1.267 & $138,146,862$ & $920,979,082$ & $-52,546,229$ \\
\hline 7 & 0.759 & $644,674,853$ & 8.061 & $486,718,527$ & $72,708,059$ & $414,010,468$ & 1.318 & $143,698,497$ & $957,989,985$ & $-43,003,161$ \\
\hline 8 & 0.730 & $619,768,540$ & 9.404 & $567,866,404$ & $72,708,059$ & $495,158,344$ & 1.371 & $149,473,234$ & $996,488,226$ & $-31,034,575$ \\
\hline 9 & 0.702 & $595,824,455$ & 10.802 & $652,275,327$ & $72,708,059$ & $579,567,268$ & 1.426 & $155,480,036$ & $1,036,533,575$ & $-16,621,888$ \\
\hline 10 & 0.674 & $572,805,424$ & 12.256 & $740,076,347$ & $72,708,059$ & $667,368,288$ & 1.483 & $161,728,231$ & $1,078,188,206$ & 257,275 \\
\hline 11 & 0.648 & $550,675,709$ & 13.769 & $831,405,781$. & $72,708,059$ & $758,697,722$. & 1.543 & $168,227,518$ & $1,121,516,789$ & $19,629,123$ \\
\hline
\end{tabular}

Table 1: Cash Position calculation table 
Am. J. Sci. Ind. Res., 2010, 1(2): 332-341

\begin{tabular}{|l|l|}
\hline YEAR OF PAYMENT & PROFIITABILITY INDEX \\
\hline 1 & 0.00057 \\
\hline 2 & 0.0189 \\
\hline 3 & 0.0255 \\
\hline 4 & 0.0291 \\
\hline 5 & 0.0316 \\
\hline 6 & 0.0336 \\
\hline 7 & 0.0353 \\
\hline 8 & 0.0368 \\
\hline 9 & 0.0381 \\
\hline 10 & 0.0394 \\
\hline 1 & 0.0407 \\
\hline
\end{tabular}

Table 2: PROFITABILITY INDEX/YEAR

Appendix 1: continued

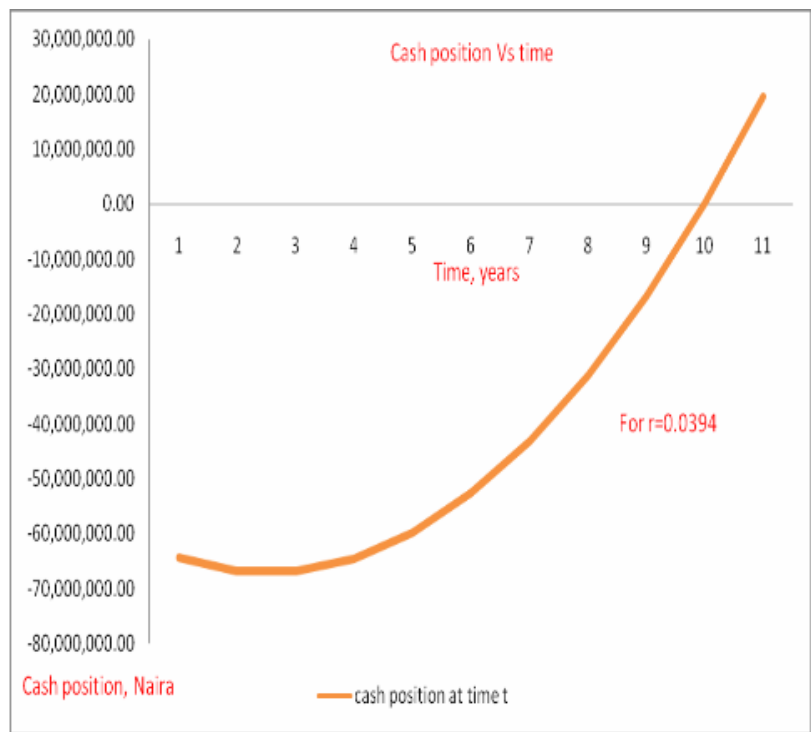

Fig 1: Graph of cash position Vs Time, for $r=0.0394$

Appendix 1: continued

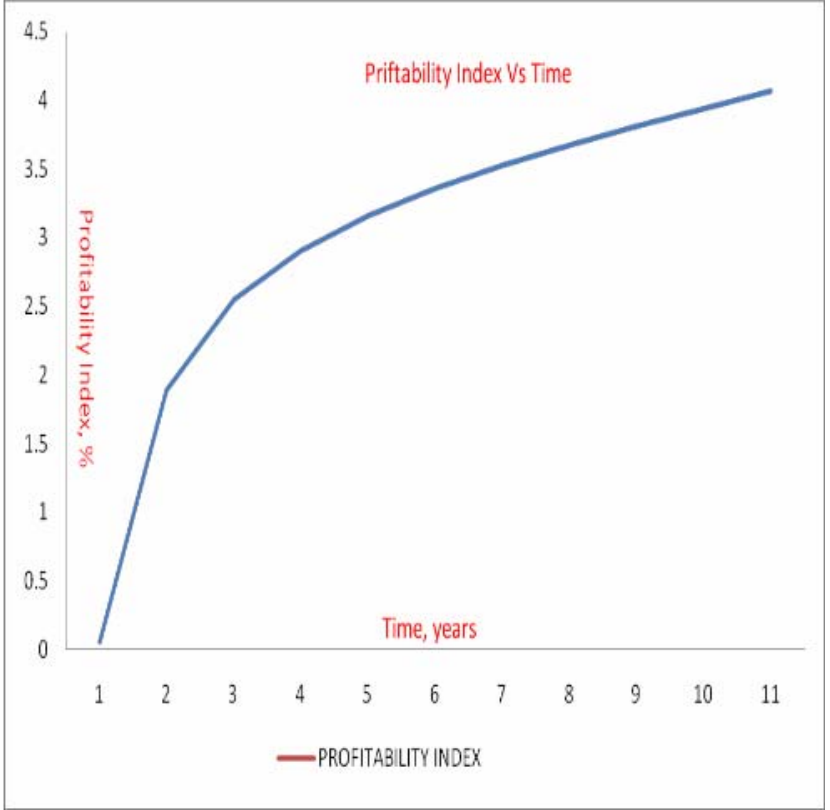

Fig 2: Graph of profitability Index Vs Time 
Am. J. Sci. Ind. Res., 2010, 1(2): 332-341

\section{APPENDIX 2: STEAM ACTIVATION OF SUGARCANE BAGASSE}

\begin{tabular}{|c|c|c|c|c|c|c|c|c|c|c|c|}
\hline$=$ & 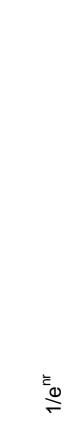 & 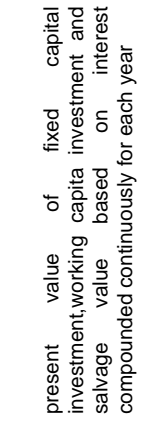 & 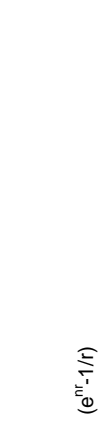 & 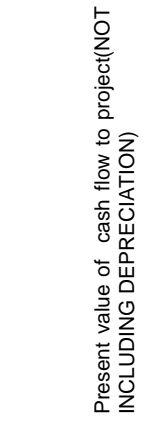 & 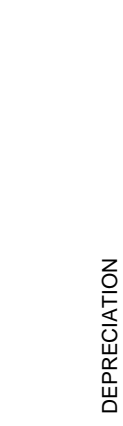 & 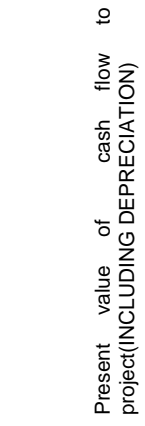 & $\Xi_{0}$ & 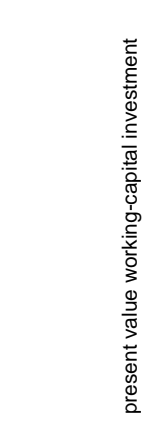 & 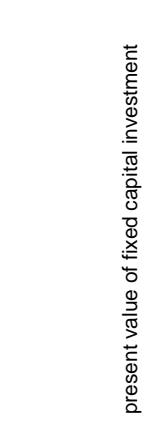 & & 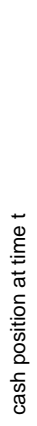 \\
\hline 1 & 0.965 & $917,789,574$ & 1.018 & $63,700,840$ & $80,990,657$ & $-17,289,817$ & 1.037 & $125,945,987$ & $839,639,915$ & $-65,086,145$ & \\
\hline 2 & 0.930 & $885,288,800$ & 2.074 & $129,740,269$ & $80,990,657$ & $48,749,612$ & 1.0747 & $130,569,723$ & $870,464,825$ & $-66,996,136$ & \\
\hline 3 & 0.898 & $853,938,944$ & 3.168 & $198,204,142$ & $80,990,657$ & $117,213,484$ & 1.114 & $135,363,207$ & $902,421,381$ & $-66,632,159$ & \\
\hline 4 & 0.866 & $823,699,249$ & 4.303 & $269,181,465$ & $80,990,657$ & $188,190,807$ & 1.155 & $140,332,669$ & $935,551,127$ & $-63,993,740$ & \\
\hline 5 & 0.835 & $794,530,402$ & 5.479 & $342,764,511$ & $80,990,657$ & $261,773,853$ & 1.198 & $145,484,570$ & $969,897,135$ & $-59,077,450$ & \\
\hline 6 & 0.806 & $766,394,483$ & 6.699 & $419,048,942$ & $80,990,657$ & $338,058,284$ & 1.241 & $150,825,608$ & $1,005,504,056$ & $-51,876,896$ & \\
\hline 7 & 0.777 & $739,254,913$ & 7.963 & $498,133,932$ & $80,990,657$ & $417,143,274$ & 1.287 & $156,362,727$ & $1,042,418,179$ & $-42,382,718$ & \\
\hline 8 & 0.750 & $713,076,410$ & 9.273 & $580,122,294$ & $80,990,657$ & $499,131,637$ & 1.334 & $162,103,124$ & $1,080,687,497$ & $-30,582,574$ & \\
\hline 9 & 0.723 & $687,824,940$ & 10.632 & $665,120,619$ & $80,990,657$ & $584,129,961$ & 1.383 & $168,054,264$ & $1,120,361,760$ & $-16,461,121$ & \\
\hline 10 & 0.697 & $663,467,676$ & 12.040 & $753,239,406$ & $80,990,657$ & $672,248,748$ & 1.434 & $174,223,881$ & $1,161,492,546$ & -3 & \\
\hline 11 & 0.673 & $639,972,952$ & 13.501 & $844,593,216$ & $80,990,657$ & $763,602,558$ & 1.487 & $180,619,999$ & $1,204,133,329$ & $18,822,182$ & \\
\hline
\end{tabular}

Table 3: Cash position calculation table for the steam activation of sugarcane bagasse

\begin{tabular}{|l|l|}
\hline N, YEAR & PROFITABILITY INDEX \\
\hline 1 & 0.089 \\
\hline 2 & 1.8 \\
\hline 3 & 2.34 \\
\hline 4 & 2.7 \\
\hline 5 & 2.9 \\
\hline 6 & 3.1 \\
\hline 7 & 3.2 \\
\hline 8 & 3.4 \\
\hline 9 & 3.5 \\
\hline 10 & 3.6 \\
\hline 11 & 3.7 \\
\hline
\end{tabular}

Table 4: Profitability Index per year for the steam activation of sugarcane bagasse

\section{Appendix 2:: continued}

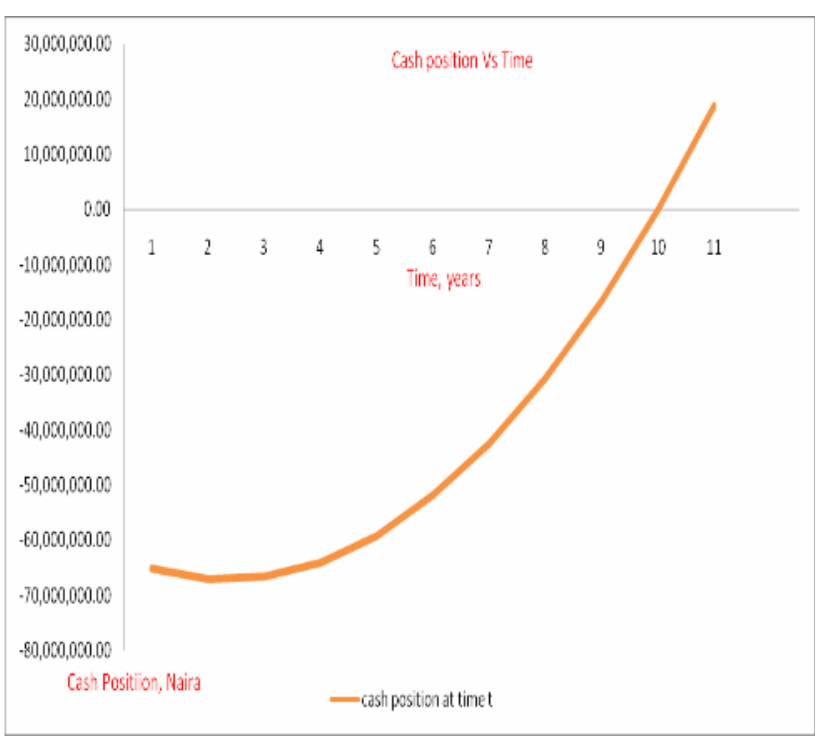

Figure 3: Graph of cash position Vs Time

\section{Appendix 2: continued}


Am. J. Sci. Ind. Res., 2010, 1(2): 332-341

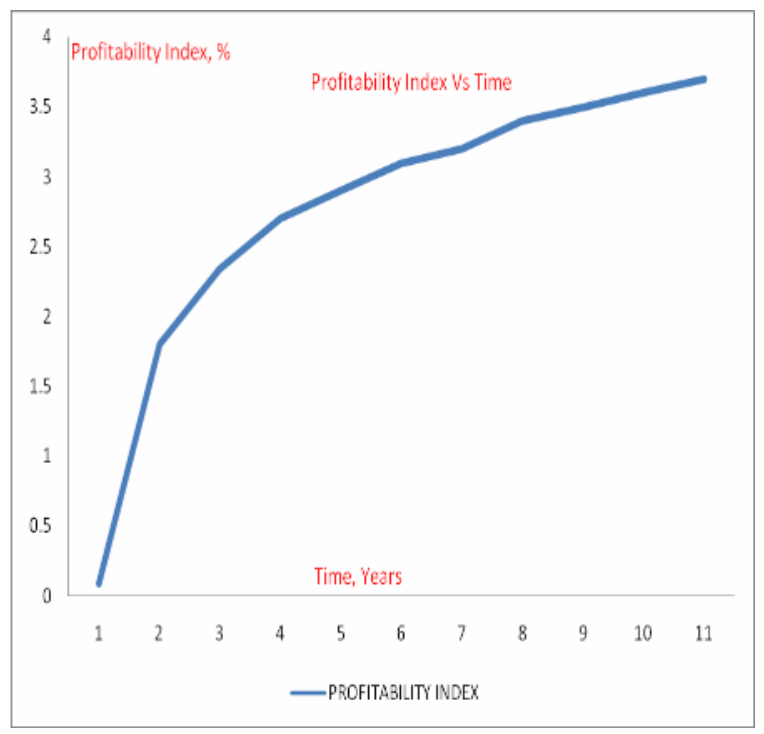

Fig 4: Profitability Index Vs Time

APPENDIX 3: PHOSPHORIC ACTIVATION OF OIL-PALM SHELLS

\begin{tabular}{|c|c|c|c|c|c|c|c|c|c|c|}
\hline$=$ & 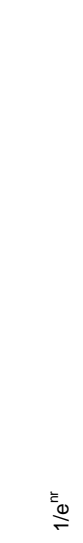 & 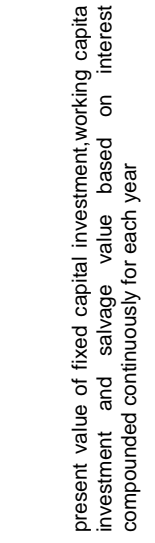 & 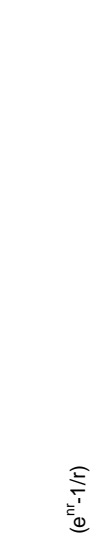 & 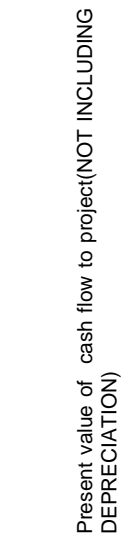 & 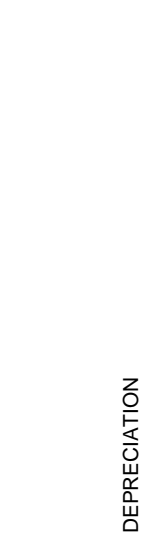 & 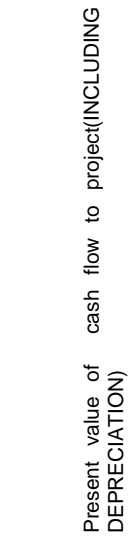 & $\bar{e}_{0}$ & 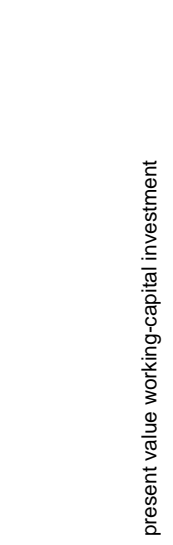 & 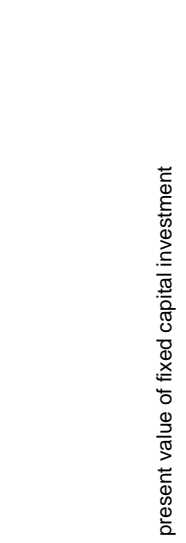 & 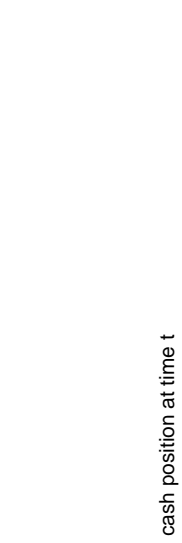 \\
\hline 1 & 0.980 & $1,124,402,974$ & 1.010 & $49,586,830$ & $97,705,605$ & $-48,118,774$ & 1.020854 & $149,614,807.06$ & $997,432,047.04$ & $-70,762,654.64$ \\
\hline 2 & 0.980 & $1,101,433,160$ & 2.0419 & $100,207,564$ & $97,705,605$ & $2,501,959$ & 1.042144 & $152,734,945.74$ & $1,018,232,971.58$ & $-67,032,797.54$ \\
\hline 3 & 0.940 & $1,078,932,585$ & 3.095 & $151,884,379$ & $97,705,605$ & $54,178,774$ & 1.063877 & $155,920,153.28$ & $1,039,467,688.55$ & $-62,276,482.36$ \\
\hline 4 & 0.921 & $1,056,891,661$ & 4.170 & $204,638,262$ & $97,705,605$ & $106,932,657$ & 1.086064 & $159,171,786.67$ & $1,061,145,244.46$ & $-56,492,712.41$ \\
\hline 5 & 0.902 & $1,035,300,999$ & 5.267 & $258,493,143$ & $97,705,605$ & $160,787,537$ & 1.108713 & $162,491,231.17$ & $1,083,274,874.47$ & $-49,677,568.38$ \\
\hline 6 & 0.884 & $1,014,151,401$ & 6.387 & $313,470,074$ & $97,705,605$ & $215,764,469$ & 1.131835 & $165,879,900.95$ & $1,105,866,006.36$ & $-41,830,036.69$ \\
\hline 7 & 0.866 & $993,433,857$ & 7.531 & $369,594,811$ & $97,705,605$ & $271,889,206$ & 1.155439 & $169,339,239.68$ & $1,128,928,264.51$ & $-32,944,440.63$ \\
\hline 8 & 0.848 & $973,139,540$ & 8.699 & $426,888,479$ & $97,705,605$ & $329,182,873$ & 1.179535 & $172,870,721.10$ & $1,152,471,474.02$ & $-23,019,781.05$ \\
\hline 9 & 0.831 & $953,259,804$ & 9.89 & $485,378,734$ & $97,705,605$ & $387,673,128$ & 1.204133 & $176,475,849.73$ & $1,176,505,664.87$ & $-12,048,581.17$ \\
\hline 10 & 0.814 & $933,786,181$ & 11.11 & $545,086,773$ & $97,705,605$ & $447,381,168$ & 1.229245 & $180,156,161.43$ & $1,201,041,076.21$ & $-29,887.56$ \\
\hline 11 & 0.797 & $914,710,374$ & 12.35 & $606,042,238$ & $97,705,605$ & $508,336,633$ & 1.25488 & $183,913,224.11$ & $1,226,088,160.75$ & $13,045,622.41$ \\
\hline
\end{tabular}


Am. J. Sci. Ind. Res., 2010, 1(2): 332-341

Table 5: cash position calculation table for the phosphoric activation of oil-palm shell

\begin{tabular}{|l|l|}
\hline YEAR OF PAYMENT & REQUIRED INTEREST \\
\hline 1 & -1.08546 \\
\hline 2 & 0.555 \\
\hline 3 & 1.12 \\
\hline 4 & 1.41 \\
\hline 5 & 1.61 \\
\hline 6 & 1.74 \\
\hline 7 & 1.84 \\
\hline 8 & 1.93 \\
\hline 9 & 1.999 \\
\hline 10 & 2.064 \\
\hline 11 & 2.122 \\
\hline
\end{tabular}

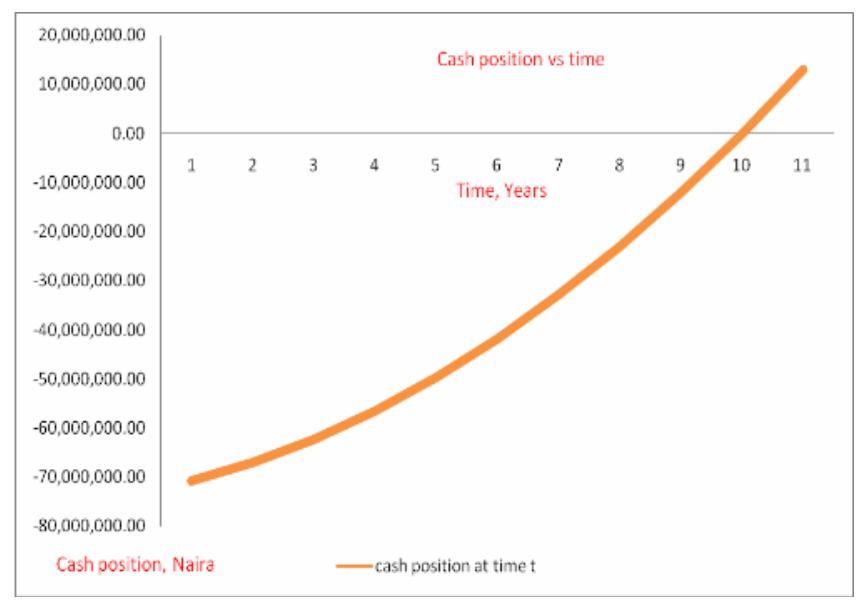

Figure 5: Graph of Cash position Vs Time

Table 6: profitability Index per year table

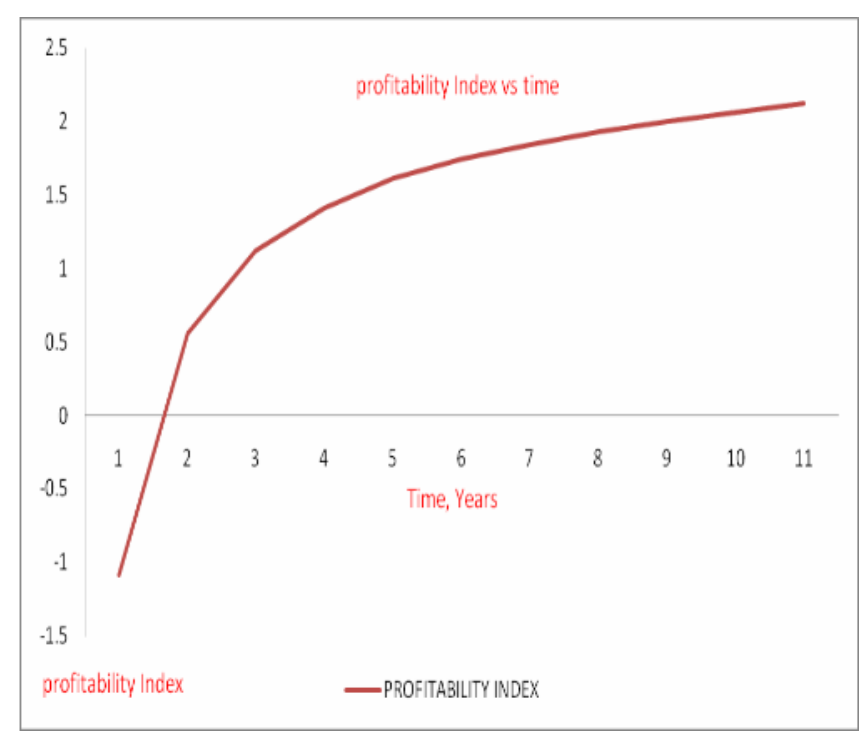

Fig 6: Graph of Profitability Index Vs Time

APPENDIX 4: STEAM ACTIVATION OF COCONUT SHELLS

\begin{tabular}{|l|l|l|l|}
\hline Equipment cost & Total product cost & $\begin{array}{l}\text { Reduction in Total product } \\
\text { cost }\end{array}$ & $\begin{array}{l}\text { Percentage reduction in total product cost for } \\
\text { 10\% successive reduction In equipment costs }\end{array}$ \\
\hline $1.33 \mathrm{E}+08$ & $603,830,502.00$ & & \\
\hline $1.19 \mathrm{E}+08$ & $589,121,837.75$ & $14,708,664.25$ & 2.44 \\
\hline $1.07 \mathrm{E}+08$ & $575,884,039.57$ & $13,237,798.18$ & 2.25 \\
\hline $9.67 \mathrm{E}+07$ & $563,970,021.21$ & $11,914,018.36$ & 2.07 \\
\hline $8.71 \mathrm{E}+07$ & $553,247,404.69$ & $10,722,616.52$ & 1.90 \\
\hline $7.84 \mathrm{E}+07$ & $543,597,049.82$ & $9,650,354.87$ & 1.74 \\
\hline $7.05 \mathrm{E}+07$ & $534,911,703.44$ & $8,685,346.38$ & 1.60 \\
\hline $6.35 \mathrm{E}+07$ & $527,094,943.00$ & $7,816,760.44$ & 1.46 \\
\hline $5.71 \mathrm{E}+07$ & $520,059,834.30$ & $7,035,108.70$ & 1.33 \\
\hline $5.14 \mathrm{E}+07$ & $513,728,236.47$ & $6,331,597.83$ & 1.22 \\
\hline
\end{tabular}


Table 7: Table showing \% reduction in the total productive cost for each successive $10 \%$ reduction in equipment cost

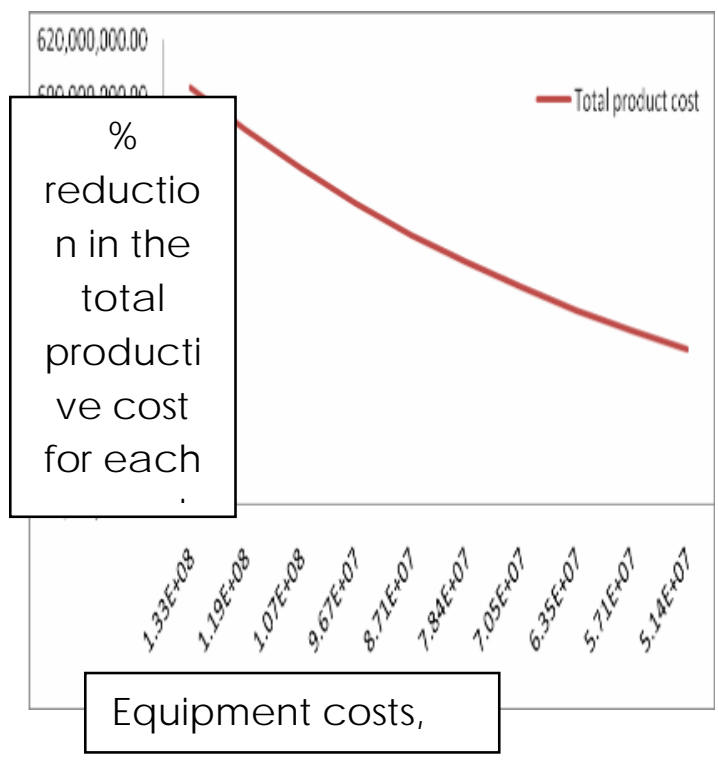

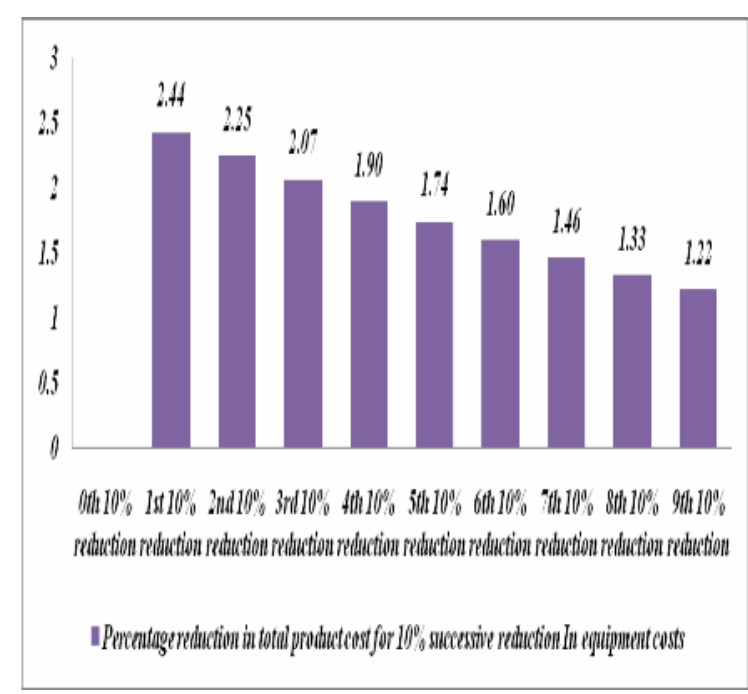

Fig 8: Bar chart showing \% reduction in total product cost for $10 \%$ cost in equipment costs

Fig 7: the graph of Total productive costs Vs equipment cost

Appendix 4 cotinued

APPENDIX 5: STEAM ACTIVATION OF SUGARCANE BAGASSE

\begin{tabular}{|l|l|l|l|}
\hline & & & $\begin{array}{l}\text { Percentage reduction in } \\
\text { total product cost for 10\% } \\
\text { successive reduction In } \\
\text { equipment costs }\end{array}$ \\
\hline $2.01 \mathrm{E}+08$ & Total product cost & Reduction in Total product cost & 0 \\
\hline $1.81 \mathrm{E}+08$ & 631203554.5 & & 2.85 \\
\hline $1.61 \mathrm{E}+08$ & 613224862 & 17978692.45 & 2.93 \\
\hline $1.41 \mathrm{E}+08$ & 595246169.6 & 17978692.44 & 3.02 \\
\hline $1.21 \mathrm{E}+08$ & 577267477.1 & 17978692.45 & 3.11 \\
\hline $1.00 \mathrm{E}+08$ & 559288784.7 & 17978692.44 & 3.21 \\
\hline $8.04 \mathrm{E}+07$ & 541310092.2 & 17978692.45 & 3.32 \\
\hline $6.03 \mathrm{E}+07$ & 523331399.8 & 17978692.45 & 3.44 \\
\hline $4.02 \mathrm{E}+07$ & 505352707.3 & 17978692.44 & 3.56 \\
\hline $2.01 \mathrm{E}+07$ & 487374014.9 & 17978692.45 & 3.69 \\
\hline
\end{tabular}

Table 8: Table showing \% reduction in the total productive

cost for each successive $10 \%$ reduction in equipment cost 


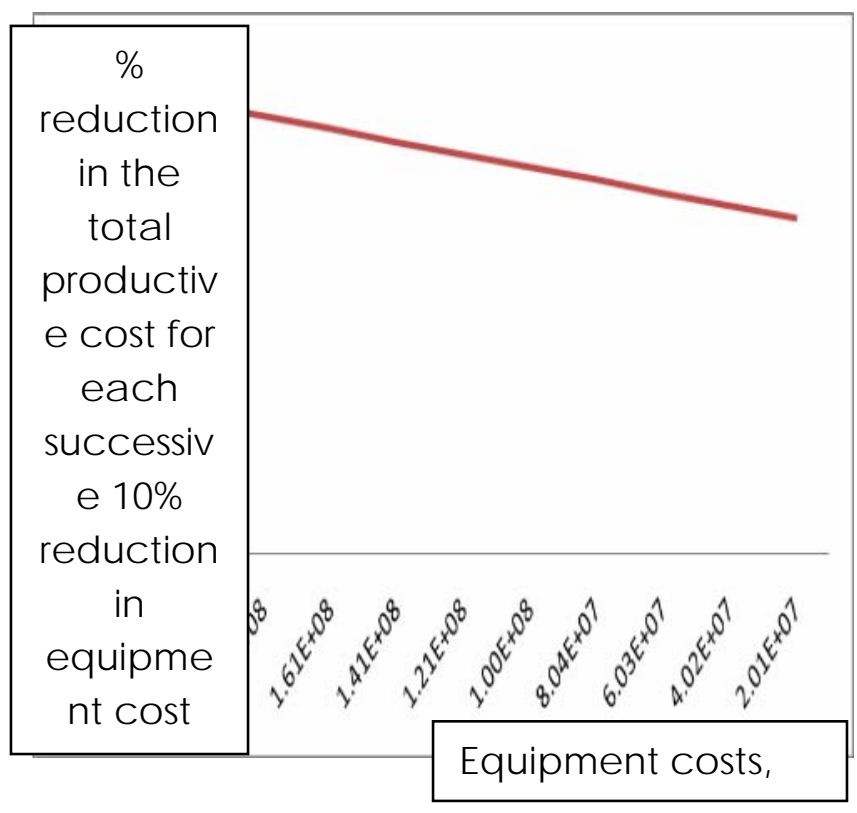

Fig 9: the graph of Total productive costs Vs equipment cost

\section{APPENDIX 5; CONTINUED}

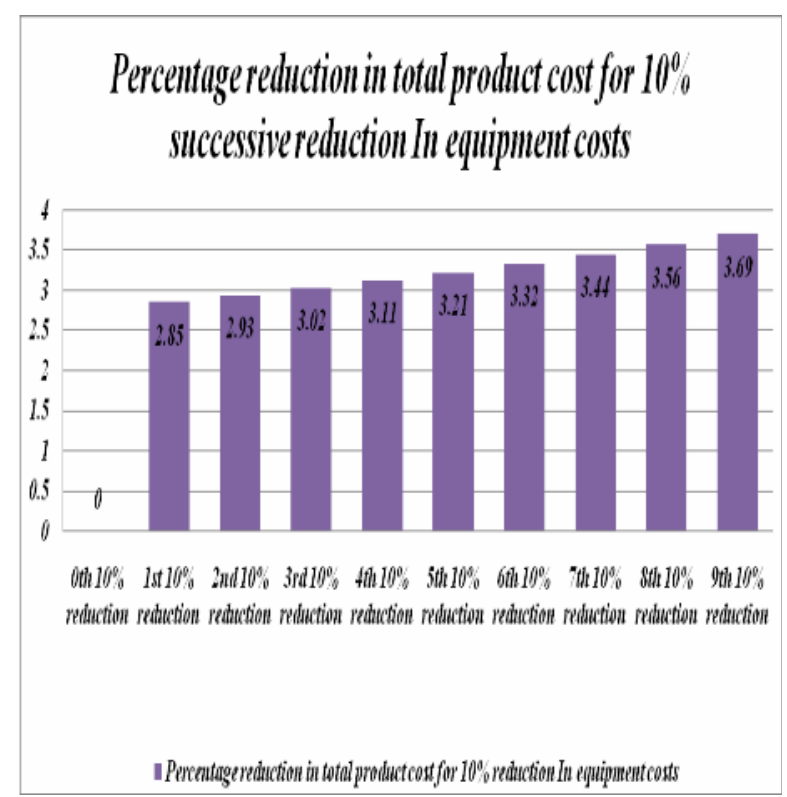

Fig 10: Bar chart showing \% reduction in total product cost for $10 \%$ cost in equipment costs

APPENDIX 6: PHOSPHORIC ACID ACTIVATION OF SUGARCANE BAGASSE

\begin{tabular}{|l|l|l|l|}
\hline Equipment cost & Total product cost & Reduction in product cost & $\begin{array}{l}\text { Percentage reduction for } \\
\text { ro\% } \\
\text { equipment costs }\end{array}$ \\
\hline $242,373,500.00$ & $473,969,728.00$ & & \\
\hline $218,136,150.00$ & $452,280,572.44$ & $21,689,155.56$ & 4.58 \\
\hline $196,322,535.00$ & $432,760,331.85$ & $19,520,240.59$ & 4.32 \\
\hline $176,690,181.50$ & $415,192,025.84$ & $17,568,306.01$ & 4.06 \\
\hline $159,021,163.40$ & $399,380,639.96$ & $15,811,385.88$ & 3.81 \\
\hline $143,119,047.10$ & $385,150,392.65$ & $14,230,247.31$ & 3.56 \\
\hline $128,807,142.40$ & $372,343,170.05$ & $12,807,222.60$ & 3.33 \\
\hline $115,926,428.20$ & $360,816,669.74$ & $11,526,500.31$ & 3.10 \\
\hline $104,333,785.40$ & $350,442,819.44$ & $10,373,850.30$ & 2.88 \\
\hline $93,900,406.86$ & $341,106,354.19$ & $9,336,465.25$ & 2.66 \\
\hline
\end{tabular}


Table 9: Table showing \% reduction in the total productive cost for each successive $10 \%$ reduction in equipment cost

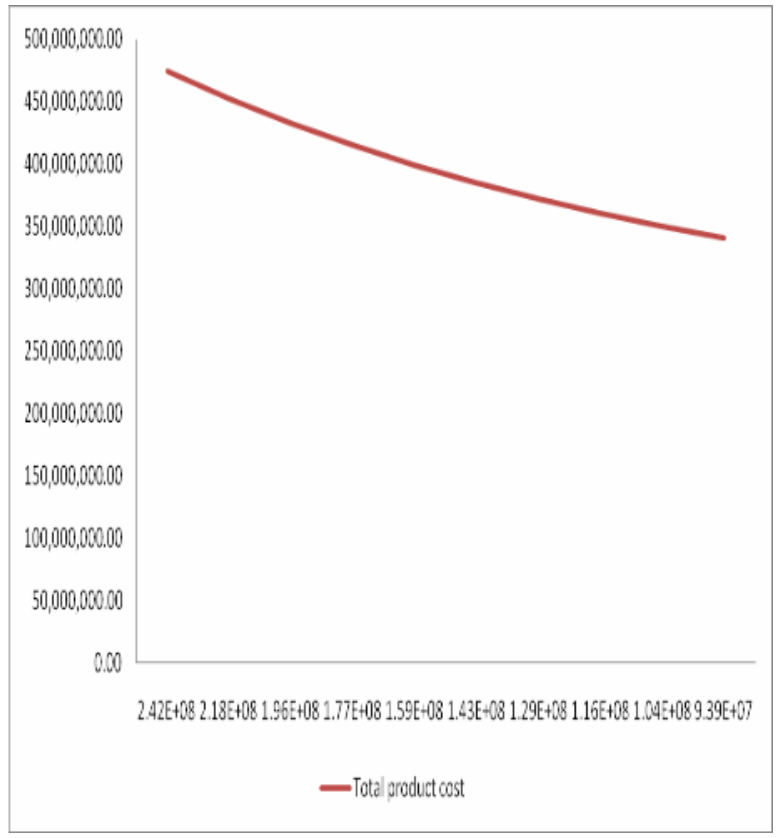

Fig 11: the graph of Total productive costs Vs equipment cost

APPENDIX 6: CONTINUED

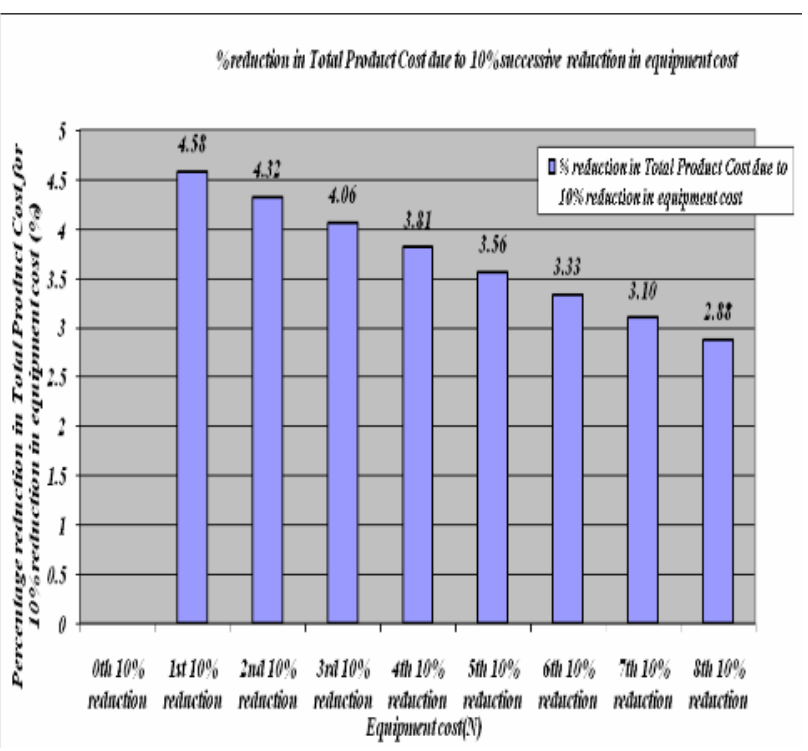

Fig 12: Bar chart showing \% reduction in total product cost for $10 \%$ cost in equipment costs

\section{REFERENCES}

Baasel, W. D., "Preliminary Chemical Engineering Plant Design." Americal Elsevier, New York, 1976. agricultural by-products. Bioresource Technol. 69, 4551.

Holland, F. A., F. A watson, and J. K. Wikilson, Engineering Economics for Chemical Engineers,, Chem Engr. (1973)

Odesola, I.F. and Daramola N.( 2009). Developing a local capability for the manufacture of activated carbon from agricultural waste. Pacific Journal of Science and Technology, U.S.A, Vol. 10, No.2.

Park, W. R., " Cost Engineering Analysis: a Guide to the Economic evaluation of engineering projects," j. Willey and sons, New York, 1973.

Peters, M., and Timmerhaus, K., 1958. Plant Design and Economics for Chemical Engineers. McGraw-Hill, Inc., New York. 